\title{
Prices of conventional and renewable energy as determinants of sustainable and secure energy development: regression model analysis
}

Sandi Knez ${ }^{1}$ Goran Šimić ${ }^{*} \mathbb{D}$, Anica Milovanović ${ }^{3}$, Sofia Starikova ${ }^{4}$ and Franc Željko Županič ${ }^{5}$

\begin{abstract}
Background: The prices of energy resources are important determinants of sustainable energy development, yet associated with significant unknowns. The estimates of the impact of prices of energy products in the domestic market (for domestic consumers) are rare-hence the importance and novelty of this research. Therefore, the main goal of the paper is to assess the impact of domestic prices of gasoline, gas, coal, and solar energy on sustainable and secure energy future.

Methods: The research includes 14 countries (of which 7 are developed and 7 are developing countries) and a period of 5 years (2014-2018). The model also includes discrete variables: level of development (developing or developed), and the fact as to whether the country is an energy exporter or not. For the purposes of analysis, the following elements were used: Panel Data Analysis, Linear regression (with random and fixed effects), Durbin-Wu-Hausman test, and Honda test, with the use of $R$-studio software for statistical computing.
\end{abstract}

Results: The research showed that the biggest negative impact on energy sustainability was recorded by an increase in the price of coal and the smallest one by an increase in the price of solar energy. An increase in the price of gasoline has a positive impact, while an increase in the price of gas has no impact. The basic methodological result showed that the fixed effects linear model is more accurate than the random effect model.

Conclusions: The results of the paper, important as a sustainable energy policy recommendation, showed that the impact of changes in energy product prices is significantly greater in developing countries, but that the status of the country as an energy exporter has no significance. In addition, the paper points to the need to intensify the research on the assessment of the impact of energy product prices for domestic consumers on their ability to pay that price, because with a certain (so far undefined) increase in energy product prices, a certain group of domestic consumers moves into a category that is not in line with sustainable energy development and is extremely undesirable in every respect-energy poverty.

Keywords: Sustainable energy development, Conventional energy prices, Solar prices, Developing countries, Developed countries, R-studio

\footnotetext{
*Correspondence: gshimic@gmail.com

${ }^{2}$ Department for Simulations and Distance Learning, University

of Defense in Belgrade, Pavla Jurišića Šturma 1, 11000 Belgrade, Republic of Serbia

Full list of author information is available at the end of the article
}

\section{Background}

Stability, sustainability and reliability of energy systems are very important basic preconditions for progress based on sustainable development, climate change mitigation and low carbon economy. Sustainable energy development is defined as SDG 7 within Sustainable Development Goals, and it implies affordable and clean 
energy for all, with an emphasis on electricity for residential areas, both urban and rural [1]. The inequalities that exist in terms of energy access and opportunities for improvement in this regard should be borne in mind [2] Specifically, one-fifth of humanity does not have access to electricity, but there are also differences in the production of energy from renewable sources among the most developed countries [3]. Developed countries consume large amounts of energy and cause the greatest pollution, i.e., make the greatest contribution to climate change [4, 5]. Moreover, only a small number of countries in the world have the largest reserves of energy resources, while most countries are energy importers [6]. When complex geopolitical challenges are considered, it is evident that stable and sustainable energy development is certainly one of the most dynamic systems [7].

Therefore, energy systems have their technical, economic, environmental, social, and political dimensions, with a large number of related variables, which intertwine in very complex ways, where it is certainly necessary to emphasize that there is no single consensus on the number and type of indicators that can measure sustainable energy development [8]. Sustainable energy development is defined through a large number of policies, strategies, action plans, and other documents, at all levels, which makes it relatively complex when it comes to studying individual policies, institutional and regulatory frameworks. According to the World Bank report, the initial meaning and goals of SDG 7 may be modified depending on decision-makers and policies in certain countries [9]. Difficulties in determining the directions of sustainable energy development are reflected in the fact that mutual impacts of variables are not clearly and unambiguously defined, whereby the changes differ in type (positive, negative, or neutral) and intensity. In addition, the interrelationship of factors influencing sustainable energy development is different in individual countries, regions, and/or time periods [10]. The apparent global impact of climate change is leading to the growing importance of carbon reduction, making the assessment even more complicated [11]. Therefore, detailed studies of the impact of certain factors on sustainable energy development are of particular interest.

The availability of energy resources and energy prices have a significant impact on the stable and sustainable development of every country, but the policies that determine the goals and necessary activities change depending on the priority of each country, which is usually conditioned by the level of economic development. In the case of the poorest countries, which are often financially over-indebted, economic activities are commonly based solely on the need to generate income, with the environment being degraded and the local population living in difficult conditions, at or below the poverty line and with limited access to energy, while a certain part of the population does not have access to energy at all. All of the above leads to the conclusion that the development of this group of countries is not based on the principles of sustainability, nor on the principles of basic SDGs [12].

In developing countries, there is generally a commitment to sustainable energy development, but the concrete implementation is hampered by the insufficient economic strength of these countries, which are often highly dependent on imports of energy products. In addition, more intensive use of energy from renewable sources and the introduction of cleaner technologies are limited due to insufficient funds available in the form of budgets, or domestic and foreign investments [13].

Emerging economies constitute a special group of countries recording strong economic growth and being large importers or exporters of energy products, but also contributing to global pollution, so sustainable energy development in these countries is of particular importance. Namely, strong economic development requires large amounts of energy products, and the practice has shown frequent use of outdated technologies and generation of pollution [14]. Having accumulated some wealth, these countries can switch to environmentally friendly technologies, but this occurs relatively slowly and inconsistently [15].

Having in mind SDG 7, the subject of this paper is the assessment of the impact of energy product prices on the stability and sustainability of energy systems, with emphasis on the security of supply. Namely, energy product prices determine affordability, i.e., the ability of countries and their citizens to provide a sufficient quantity of energy products for their own needs. In a way, energy sustainability and energy security essentially overlap [16].

Comprehensive research entitled Energy security: Definitions, dimensions and indexes, dated 2015, defines seven basic dimensions of energy security: energy products availability, infrastructure, energy product prices, social dimension, environmental aspects, management, and energy efficiency, which significantly overlaps with the definition of energy sustainability that is "related with the provision of adequate, reliable, and affordable energy, in conformity with social and environmental requirements" [17].

International Energy Agency considers the short-term approach to energy security exclusively as the ability of the energy system of a country to respond immediately and in the best possible way to changes in the balance between supply and demand [18]. On the other hand, the long-term approach to energy security is focused on finding and implementing supplies that are in line with a long-term, planned economic development, along 
with the need to preserve the quality of the environment (Energy Supply Security: The Emergency Response of IEA Countries-2014 Edition). UNDP-the United Nations Development Programme defines energy security as "the continuous availability of energy in varied forms, in sufficient quantities and at affordable prices" [19].

In general, measuring of energy sustainability is associated with a large number of challenges [20], whereby sustainable energy development is influenced by numerous factors, the number of which is neither defined nor considered final [21].

However, the common thread running through all these definitions, approaches, and specificities of energy sustainability and energy security is that the prices of conventional and renewable energy sources play an important role in maintaining (in)stability of energy systems and their (un)sustainable development, which is the subject of study by the academic community. The method for pricing of energy products is specific, and it is not the subject of this paper, but the volatility of prices, different ways of regulation, as well as government interventions, must be borne in mind, since all this leads to price changes, so their impact on sustainable energy development may change over time [22]. Coal is the only conventional energy source whose price is relatively stable, does not record a high degree of volatility, and, viewed exclusively from that side (without considering the environmental effects), can be considered a source that positively affects energy stability [23].

In the long run, rising prices of energy products affect economic development as a whole [24], whereby rising prices of non-renewable energy products should stimulate energy production from renewable sources and cause a reduction in carbon emissions due to a substitution effect [25]. A similar conclusion was reached in research dated 2020, which further found that prices of energy products have a stronger impact on reducing carbon emissions than consumption of energy from renewable sources [26]. In addition, there are evidences that prices of energy from renewable sources have a positive impact not only on SDG 7, but on SDG 8, related to decent work and economic growth, and also on SDG 13-climate action [27].

It is particularly difficult to predict the impact of changes in oil prices on sustainability, due to the specificities of pricing and the impact of geopolitical factors [28]. The prices of energy products affect many aspects of sustainable energy development. First of all, it is evident that rising energy product prices affect the reduction of energy consumption per unit of GDP [29] and energy intensity improvements in the industrial sector in developing countries [30], as well as in the USA [31]. Changes in energy prices are sometimes very sudden, which has a shock effect on the economy, the consequences of which are significant, with an indefinite duration and often unpredictable [32]. Energy prices are especially important for households, because high prices can cause energy poverty, for the alleviation of which there is currently no adequate response from governments around the world, regardless of the degree of development [33]. Certainly, special attention should be paid to developing countries, because it is expected that $90 \%$ of population growth by 2050 will be recorded in these countries, so it can be expected that the existing energy poverty will increase proportionately [34]. In addition, infrastructure, institutions, and governance in these countries can enable or constrain sustainable energy development, regardless of energy prices [35]. Investments in clean energy projects are sensitive to changes in prices, but they are greatly influenced by the volatility of the energy market, which has a significantly stronger impact than the nominal value of rising or falling oil prices [36].

In summary, the prices of conventional and renewable energy products are interrelated with economic growth, energy poverty, energy security, energy equity, and environmental sustainability, with a large number of interdependencies [37]. It should be borne in mind that forecasts for oil and gas price movements are unreliable, while solar energy prices are expected to continue to fall, although it is not clearly defined whether the reason for falling prices is a real cost reduction, or whether there are hidden subsidies in some countries, because investment projects in solar energy production are very often supported by states [38]. The outcome of this research will contribute to the research of the impact of energy product prices for domestic consumers, it will point out the differences that exist on this basis between developing and developed countries, and the assessment of the impact of the fact, on a country's energy stability, as to whether the country is an energy exporter, will also be conducted.

\section{Methods}

\section{Research sample and data sources}

The research sample consists of 14 countries at different levels of economic development and with different impacts on the global energy market, whereby both importers and/or exporters of energy products are:

1. Seven developed countries, which are also energy importers: Germany, Denmark, Canada, Norway, USA, South Korea, and Japan.

2. Seven developing countries, which are importers and/or exporters of energy: Brazil, Venezuela, India, China, Russian Federation, Saudi Arabia, and Turkey. 
The research period is conditioned by several limitations, the most important being the availability of data. Namely, data on prices of energy products are available daily, but data on the level of energy security of a particular country are available after 2 or 3 years of processing. Therefore, the research period covers 5 years, from 2014 to 2018 inclusive.

The level of energy security-data sources. There are several world agencies and bodies, as well as individual institutions dealing with an energy security assessment. For the purposes of the research, the most complete database with a sufficiently long time series will be used, i.e., the database of the U.S. Chamber of Commerce. The index was calculated by aggregating 29 individual indicators, applying selected weighting coefficients in the following groups: global fuels, fuel import, energy expenditures, price and market volatility, energy use intensity, transportation sector, electric power sector, environmental research and development, as presented in the Index of U.S. Energy Security Risk, the 2020 edition [39].

The prices of energy products whose impact will be examined are: gasoline (as oil derivative), natural gas, coal, and solar energy.

Gasoline prices in the domestic market-data sources. Data for European countries will be collected from the official Eurostat database, for the U.S. data, the official U.S. Energy Information Administration [40] database will be used. Data for Canada will be obtained from the official database of the Ministry of Natural Resources Canada [41].

Data for Brazil will be obtained from the official source: Brazilian National Agency of Petroleum, Natural Gas and Biofuels [42], and data for Venezuela from the Ministry of the People's Power for Petroleum [43]. Domestic prices of gasoline in the Russian Federation will be obtained from the Federal State Statistics Service (Rosstat) [44]. Data for Turkey will be provided through the official website of the largest oil company in Turkey: Türkiye Petrolleri [45]. Gasoline prices in India are made available on the official website of India's largest oil and gas company: Indian Oil [46].

When it comes to Asian countries, domestic gasoline prices in China are officially monitored on the website of the National Bureau of Statistics of China [47], data for Japan are made available on the official website of the Agency for Natural Resources and Energy of Japan [48], and for South Korea on the official website of the Statistical Database - Energy Sector [49].

The US \$ per liter of gasoline is used as the unit price.

Natural gas prices in the domestic market for final consumers (households)_data sources. Prices for European countries are made available at the official Eurostat database [50]. In the case of Norway, the official data of the
Norwegian international company Equinor will be used. Prices for the USA are obtained through the official website of the U.S. Energy Information Administration, and data for Canada through the official website of the largest Canadian natural gas corporation: Gas Alberta Inc [51].

When it comes to the countries of South America, the prices of natural gas for Brazil are made available on the official website of the Brazilian National Agency of Petroleum, Natural Gas and Biofuels, and data for Venezuela will be obtained through the official website of a national company Petroleos de Venezuela SA [52].

Data for the Russian Federation are made available on the official website of the largest company for the production and trade of natural gas, Gazprom. Natural gas prices for end consumers in India are monitored by the official statistics department of Indian Oil and for China by the National Bureau of Statistics of China, while data for South Korea are made available on the official website of the Statistical Database-Energy Sector.

BTU (British Thermal Unit) will be used as the unit price.

Coal prices in the domestic market-data sources. Prices for European countries, as well as data for Turkey, are made available in the official database of British Petroleum. The official U.S. Energy Information Administration database will be used for U.S. coal prices. Data for Canada will be obtained from the official database of the Ministry of Natural Resources Canada.

Coal prices in Brazil will be obtained through the official website of the Brazilian Chamber of Commerce, and for Venezuela through the official website of the $U S$ Energy Information Administration. Coal prices in the Russian Federation will be obtained from the Federal State Statistics Service (Rosstat). Data for India are made available on the official website of India's largest coal mining company Coal India Ltd [53].

Coal prices in China are monitored by the The Chinese General Chamber of Commerce [54], and in Japan by the Shinden Net agency. Data on coal prices in South Korea are made available on the official website of the Statistical Database-Energy Sector.

The U.S. dollar per ton of coal will be used as the unit price.

Solar energy production prices-data sources. The prices of solar energy production are chosen, because solar energy is currently the most widespread way of obtaining energy from renewable sources, within which solar panels are used to produce electricity. In addition, solar energy prices have been declining for a long time, while the trend for energy prices from other renewable sources is still not clearly defined [55]. To determine the price of electricity in $k W h$, it will be necessary to use LCE-levelized cost of electricity i.e., leveled costs, 
variable by year. Data on these prices are made available on the official website of IRENA-International Renewable Energy Agency [56].

\section{Data processing methods}

First, a database was created and a panel analysis (Panel Data Analysis) was conducted to enable the analysis of a large number of data over a longer period of time. In this particular case, an analysis was conducted to assess the impact of four selected energy product prices on energy security over 5 years.

After the analysis, a regression model is to be developed based on the obtained data, whereby two models will be developed, used, and compared: Model with random effects and Model with fixed effects.

Durbin-Wu-Hausman Test is used to check the suitability of developed models for application to a selected data set. It is used to compare the model with random effects and the model with fixed effects. Durbin-WuHausman Test is very important for the selection and evaluation of parameters, depending on the compromise between accuracy and precision of the fixed and random effects estimator [57].

Honda test is a test of the significance of variables, which serves to determine heteroskedasticity in linear regression, i.e., to determine errors in the developed model [58].

$R$-studio is used for statistical computing.

\section{Results}

The development of a model for estimating the impact of selected energy product prices on the stable and safe functioning of energy systems, to ensure a sustainable energy future, has been done gradually. First of all, it was assumed that prices of the 4 selected energy resources (oil, gas, coal, and solar) have a greater impact on energy security in developing countries than in developed countries. In addition, the intention was to report the impact of data on whether the country is an exporter of energy or not. A linear regression model was applied in the research (Eq. 1):

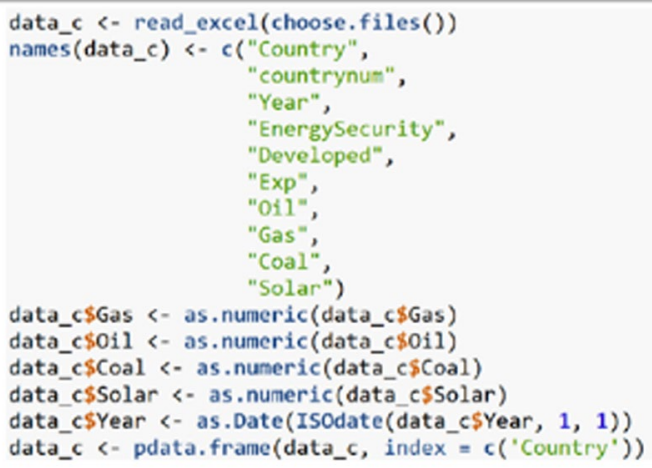

Fig. 1 Data entry into the R-studio software package

terms $\varepsilon_{i t}$ that allow to express impacts of other empirical factors emerging in the specified period.

The software for statistical data processing $R$-studio (https://www.rstudio.com/) was used in the implementation. In the first stage of research (Fig. 1), data were prepared for processing. The data were first imported into a matrix structure called data_c (line 1), then the columns were named (lines 2-10), the data were converted to a target type (lines 11-15), indexed by country, and converted to a pdata.frame structure ready for processing (line 16).

In the second stage, the analysis was performed using two methods of data sampling: Model with random effects and Model with fixed effects.

\section{Linear regression, random intragroup effect}

The analysis was first performed using the Model with random effects. For this purpose, plm (built-in function of $R$-studio) was applied, with the equation, data and modifiers used having been forwarded as parameters (Fig. 2). The processing results are stored in a purpose-designed structure model.plm.full.

A model.plm.full structure contains all the results of the analysis performed. It is further shown by calling the function summary (Fig. 3). The results obtained show that this model is balanced, with the data existing on five variables related to 14 countries-as forecasted.

Logarithmic regression was used in the analysis to

$$
Y_{\mathrm{es}}=\alpha+X_{\mathrm{dl}} * \beta+X_{\mathrm{ex}} * \beta+X_{\mathrm{op}} * \beta+X_{\mathrm{gp}} * \beta+\overline{X_{\mathrm{cp}} * \beta+X_{\mathrm{sp}} * \beta+\varepsilon_{\mathrm{it}}}
$$

where $i=1, . ., N a n d t=1, . ., T$. The dependent variable $Y_{e s}$ represents the assessment of energy security, while the independent variables $X_{o p}, X_{g p}, X_{c p} \mathrm{I} X_{c p}$, respectively, represent the prices of oil, gas, coal and solar energy, multiplied by the vector of regression coefficients $\beta$. A discrete variable $X_{d l}$ indicates whether a country is developed, and $X_{e x}$ is a discrete variable that indicates whether a country is an energy exporter. The equation includes increase the significance of coefficients with small values and to make the results more meaningful and accurate. Residuals indicate that the probability distribution is normalized. The calculated coefficients indicate the importance of individual factors in the model. Three variables have significant levels of impact on energy stability-namely, the price of coal, the price of oil, and a discrete variable that represents a country's development. On the 
model.olm.full <- plm(formula - EnergySecurity $\log (011)+\log ($ Gas $)+$ $\log ($ Coal $)+\log ($ Solar $)+$ Developed + Exp, data $=$ data_c, model $=$ "random', effect $=$ "individual")

Fig. 2 R-studio function for estimating the impact of energy product prices on energy stability and security (linear regression, random effects model)

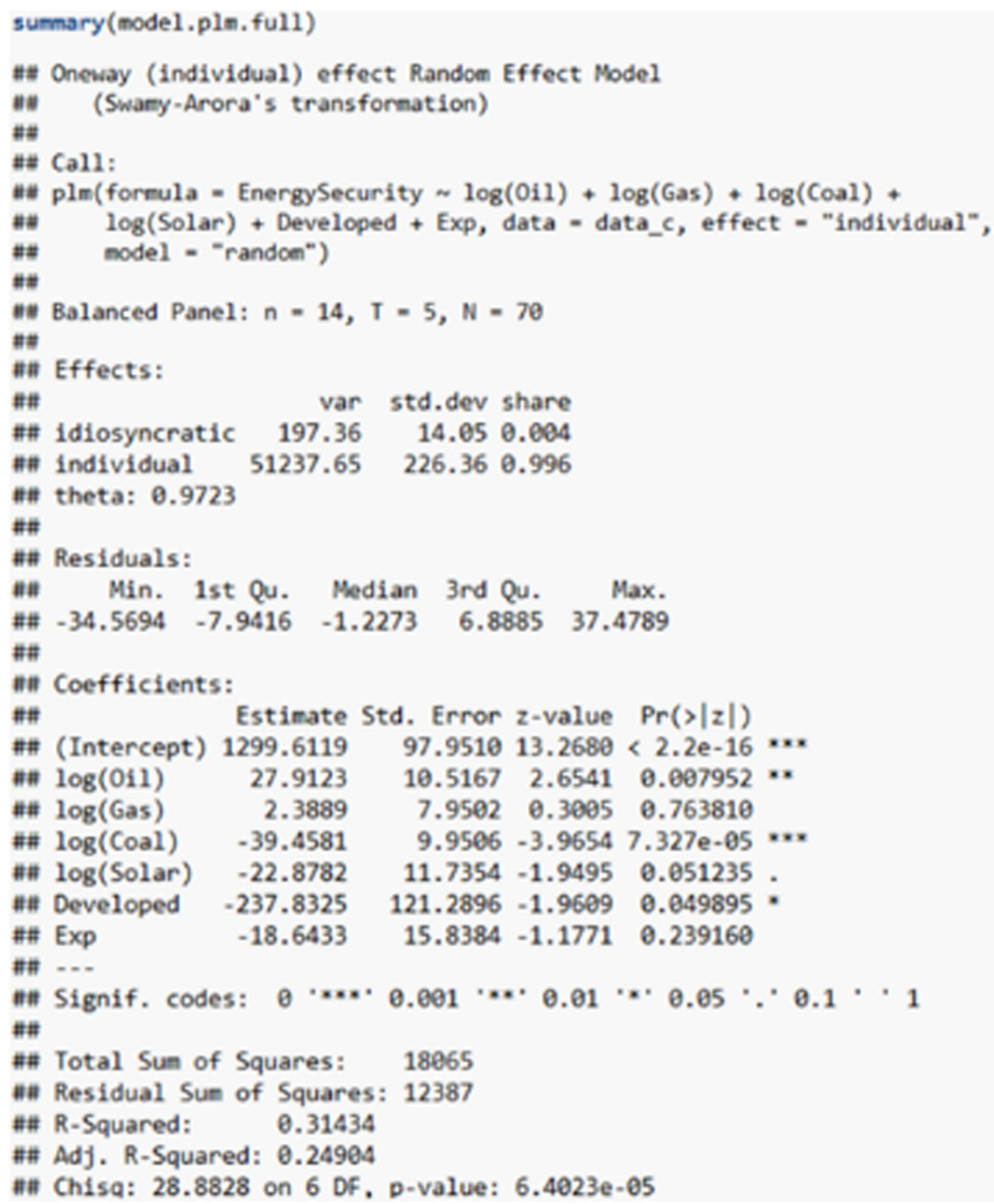

Fig. 3 Results of the assessment of the impact of energy product prices on energy stability and security (First model, linear regression, random effects) 
other hand, the price of gas, the price of solar energy, and the fact as to whether the country is an energy exporter or not do not have a satisfactory level of significance.

Based on the results obtained, the impact of factors with a satisfactory level of significance is as follows: an increase in the price of oil has a positive effect on energy stability, while an increase in the price of coal has a negative effect, whereby the impact of the price of coal is more significant than of the price to oil ( -38.4581 versus 27.9123$)$. Interestingly enough, a discrete variable that represents a country's development has a negative impact on energy stability, provided that the significance of this factor is incomparably lower than in the case of the previous two factors. It should also be noted that the impact of solar energy price on energy stability is also negative, although the significance of this factor is at the limit of acceptability $(p=0.051235)$.

In the next stage, the coefficient of determination (R-squared) was considered, showing that the accuracy of the model is 0.3134 , which can be taken as sufficiently accurate. The above implies that the model of linear regression with random effects does not show the differences when it comes to developing and developed countries. The Adjusted R-squared value of 0.24904 is not high, which indicates that the model is well balanced. A $p$ value of $6.4023 \mathrm{e}-05$ indicates that the model was adequately selected.

In summary, the application of the linear regression model with random effects determines the relationship between energy stability and security, with prices of energy products, and shows the coefficients obtained but also shows that a country level of development is of no significance.

\section{Linear regression, fixed intragroup effects}

The second model is based on the application of linear regression with fixed effects. As in the previous case, the plm built-in function of $R$-studio was used (Fig. 4), with the same equation and the same data forwarded as parameters, while the modifier model was changed to the value within. This time, the processing results are stored in a purposedesigned structure model.plm.short.

The model.plm.short structure contains the results of the performed analysis, shown by calling the function summary (Fig. 5). The data show, first and last, that the model is well balanced. The $R$-squared value of 0.34064 is higher than in the case of the model based on linear regression with random effects, which means that this model is more accurate.

Unlike the previous model, the price of solar energy in this one formally met the significance level ( $p$ value $<0.05$ ). Although still satisfactory, the price of oil in the model is less significant, while the price of coal is still a dominant factor with a large negative coefficient. Another important observation rests in the fact that the factor of a country's development in this model is completely excluded $(p=0.2998361)$.

\section{Final choice of the model for assessing the impact of energy product prices on energy stable and secure future}

At this stage of the research, a model was chosen to assess the impact of energy product prices on energy stable and secure future, based on the application of the Durbin-Wu-Hausman Test (R-studio function phtest), as shown in Fig. 6.

The values obtained in Fig. 6 (primarily a $p$ value of 0.6534) show that there are differences between the two models (linear regression with fixed or random effects), but that the model with fixed effects, recommended as the basic model for the assessment of the impact of energy product prices, is the choice of preference, while the model with random effects should be used to confirm the results.

Honda test (R-studio function plmtest), which shows the effectiveness of the significance of variables, was conducted in the next step, and the results are shown in Fig. 7.

The result of the Honda test is clear: the $p$ value $<2.2 \mathrm{e}-16$ shows that the variables used in the model with random effects are effective and significant.

The value of the average energy stability index in selected countries is 1299.6119 . The change in the logarithms of energy product prices leads to an increased risk for stable and safe energy development in the case of both the developing and developed countries, but the average increase in risk is higher by 237.8325 in the case of developing countries.

For this result to be confirmed (or refuted), the assessment of results by individual countries in a sample was performed using a model with fixed effects, and the results are shown in Fig. 8.

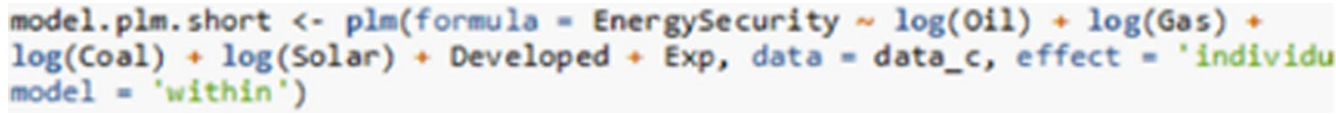

Fig. 4 R-studio function for estimating the impact of energy product prices on energy stability and security (linear regression fixed intragroup effects) 


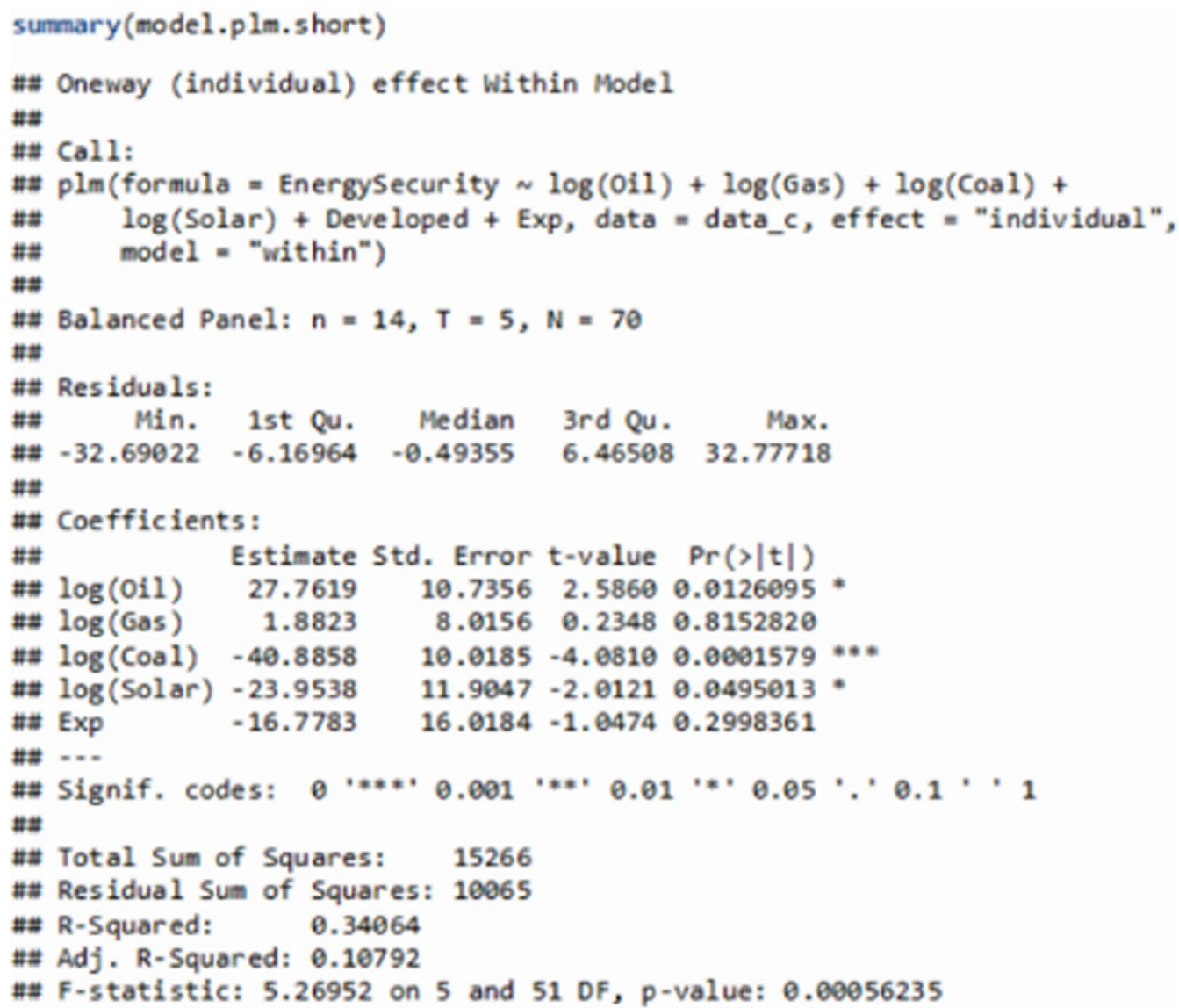

Fig. 5 Results of the assessment of energy product price on energy stability and security (linear regression, fixed intragroup effects)

phtest(model.plm.full, model.plm.short)

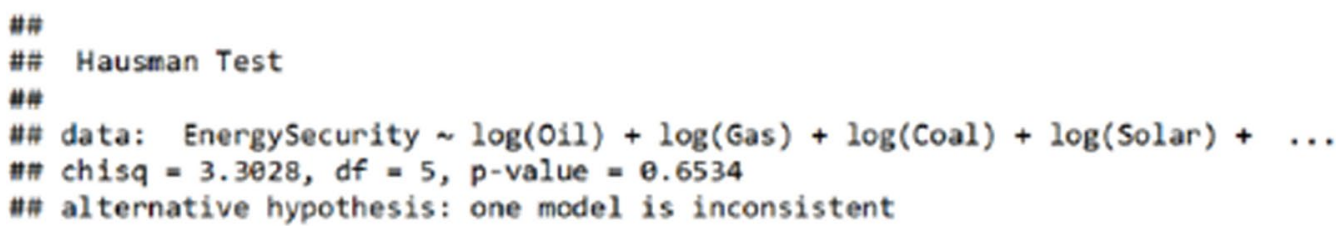

Fig. 6 Durbin-Wu-Hausman Test for the selection of a model for assessing the impact of energy product prices on energy stable and secure future

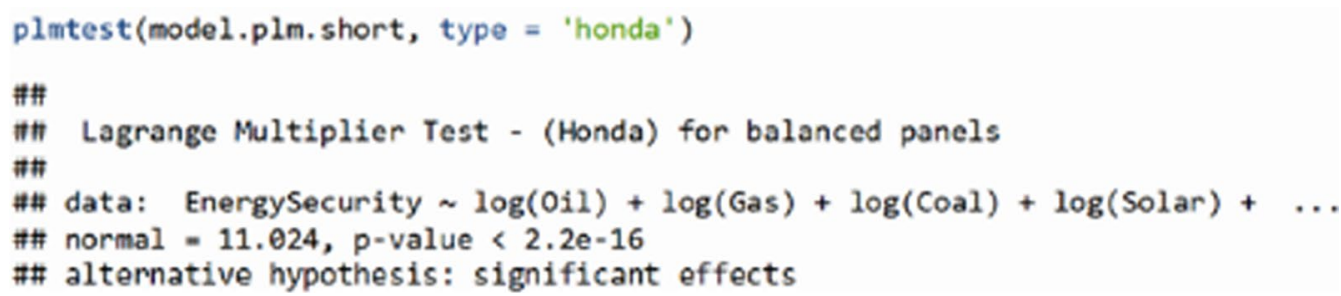

Fig. 7 Honda test for the selection of a model for assessment of effectiveness of the selected variables in a model with random effects 


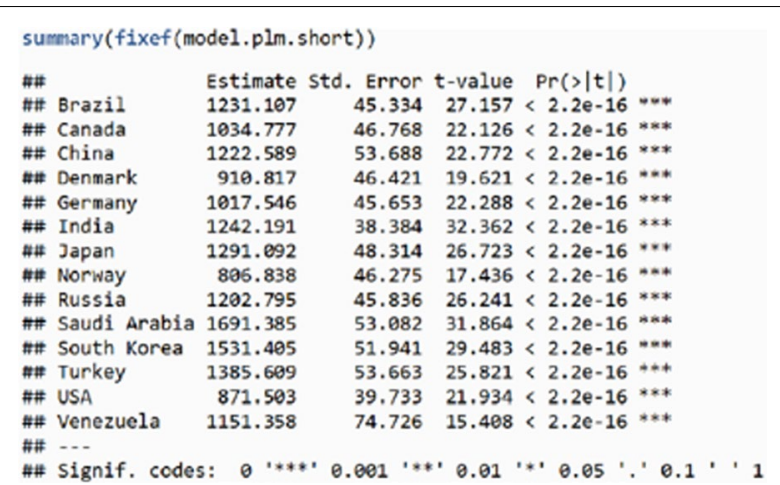

Fig. 8 Individual results of the impact of energy product prices on energy stable and secure future

The results of the analysis for the 14 selected countries confirm the previous result: changes in domestic prices of the selected energy resources have a greater impact on a stable and secure energy future in the case of developing countries than in the case of developed countries.

\section{Discussion}

The research presented in this paper has its specificities, implications, and limitations. First, the specificity of the research is reflected in the selection of the research sample, as well as the dependent and independent variables. The research connects energy prices, SDGs, and energy poverty - all of the above being very important and challenging issues at the global level, for both developed and developing countries. In addition, the research is focused exclusively on energy prices on the domestic market, i.e., it implicitly indicates the possible emergence of energy poverty. The implications of this research can be grouped as follows:

Policymaking implications raised from the fact that the research results show certain specificities that are important for policy and decision making. First, this refers to the fact that policymaking should consider the condition that solar energy prices have a significant impact on improving energy sustainability. As the stated price is constantly falling, an increased investment in obtaining energy from this source should be considered. In addition, the research shows the high importance of coal prices. Coal is certainly an environmentally unacceptable energy source, but it is widely available energy source that shows no significant correlation with geopolitical trends, so it can be considered a stable energy source. Given the importance of coal for the world economy and the turbulence in natural gas supply, decision-making regarding coal exploitation will be an increasing challenge.

Economic implications are of particular importance for the sustainable development of every country, especially when it comes to large energy-importing and energyexporting countries, since exports of energy products generate revenue, while imports generate expenditure. However, the research has shown that the fact whether a country is energy exporter or energy importer has no significance for energy sustainability, so the above-mentioned points should certainly be the subject of further research.

Social implications of the research are of particular importance, because the analysis places energy prices under review for final consumers (households). The research result which shows a drop in solar energy prices and its high impact on energy sustainability, is certainly positive for final consumers, but it should be borne in mind that, regardless of the above, installing solar panels is still expensive for a large number of residents, especially in developing countries. State assistance is certainly needed in this regard.

Main limitations of the research are reflected primarily in the reliability and updatedness of the databases used. In addition, indices used in the paper are defined by one institution (in this case, the U.S. Chamber of Commerce), so the question of how to create index can always be raised as the relevant one.

\section{Conclusions}

Energy product prices affect the development of society as a whole, in all its segments. Given the complexity of pricing of fossil fuels and energy from renewable sources, as well as the changes in global policy and acceptance of the concept of sustainable energy future, studying their impact is of particular interest. A stable, safe, secure, and sustainable energy future is certainly one of the primary goals of all countries, regardless of their level of development, or (lack of) availability of energy resources. Each country strives to provide sufficient energy for domestic consumers, by types and quantities, and certainly at an affordable price while continuously reducing the harmful effects on the environment.

No doubt, there are studies of the impact of energy product prices, but estimates of the impact of energy product prices for domestic consumers on a stable and secure energy future, and especially the studies covering a sample that would include the world's largest economies, are relatively rare. The assessment of the impact of changes in gasoline, gas, coal, and solar energy prices on a stable and secure energy future was conducted in a research sample of 14 countries (7 developing and 7 developed). The sample also includes Venezuela, as a country with significant energy resources and at a low level of development and security as a whole.

A set of methods Panel Data Analysis, Linear regression (with random and fixed effects), 
Durbin-Wu-Hausman test, and Honda test, were used in research along with the application of R-studio software for statistical computing, which was found to be methodologically adequate.

Main findings show that changes in oil, coal, and solar energy prices have an impact on a stable and secure energy future. The biggest risk to energy security is an increase in the price of coal. On the other hand, an increase in the price of oil has a positive impact on energy stability, while the change in the price of gas has no effect. The impact of the change in solar energy price is the smallest. In addition, it was found that a country's level of development has an impact on energy stability, while the fact as to whether the country is an energy exporter, and is not significant. The paper draws attention to the need for more research to focus on the situation in the market of coal as an energy product, which, although environmentally unacceptable, is still very common in the world's largest economies.

This indicates the need to change the energy policy, especially in the case of countries exporting energy products, but also has the status of developing countries. The development of these countries largely depends on the revenues they receive from energy exports, so the research into new conventional energy sources is conducted while investing in renewable energy sources is symbolic. Creating a consensus around the need to export conventional energy (at one price) and maintaining relatively low prices for domestic consumers, requires a special balance of economic and social policy measures. A particular problem rests with the case of Venezuela as a country, where riots and political turmoil have prevailed for decades, where allocation of ownership over undoubtedly plentiful energy resources is considered a priority, instead of energy product prices.

It is extremely complex to predict the importance and impact of certain factors on energy stability and sustainability in the future. However, having in mind the results of this and other recent research, it can be assumed that an increasingly pronounced collision will exist in the future between the goals of energy companies, on the one hand, and social and environmental concerns on the other. Adjustments have already begun, but increased energy poverty (which can only increase due to its demographic growth in underdeveloped and developing countries) imposes the need to look more closely at the formation of energy prices and to define policies that will save final consumers from the consequences of significant price jump. Every country must find a balance and define priorities to explore ways to ensure the stability of energy supply and thus enable economic activity while preserving the environment. A greater emphasis must be placed on finding the policies, models and solutions that will prevent the spread of energy poverty among citizens, i.e., on defining the mechanisms for its alleviation.

The directions of further research are primarily related to the development of more precise models for assessing the impact of domestic prices of energy products on various aspects of a country's development, which must be adjusted to the specificities of individual countries. In the case of all countries, attention should be paid to determining the level of energy product prices for domestic consumers as a kind of a red line beyond which prices become less affordable, which is why some domestic consumers fall into the category characterized by extremely unsustainable phenomenon-energy poverty. At the same time, in the event of an increase in energy product prices (without state aid), domestic economic activity and transport may become uncompetitive in certain areas-which opens up new challenges for a sustainable, stable, and secure future as a whole. An interdisciplinary approach to considering the issue is necessary.

\section{Acknowledgements \\ Manuscript has been translated by a professional translator Tanja Paunović, Republic of Serbia.}

\section{Authors' contributions}

SK and SS provided the research idea. SK, GŠ and FŽŽ developed the research concept of the paper. SS and AM participated in data collection. GŠ, AM and SK worked on developing a model for assessing the impact of oil, natural gas, coal and solar energy prices on the stability of energy systems. GŠ and FŽŽ prepared final manuscript draft. All coauthors participated in manuscript draft editing, revision, all coauthors approved revised version for submission. All authors read and approved the final manuscript.

\section{Funding}

Research presented in this manuscript is partially supported by the Ministry of Education, Science and Technological Development under the project MTR44007III and by AP Vojvodina, Provincial Secretariat for Higher Education and Scientific Research, Republic of Serbia, within the project "Transition of AP Vojvodina towards circular economy: analysis of the level of knowledge and definition of inputs for strategic design", Project No. 142-451-2589/2021-01/1.

Availability of data and materials

All data generated or analyzed during this study are included and cited properly in this published article.

\section{Declarations}

Ethics approval and consent to participate

Not applicable.

Consent for publication

Not applicable.

\section{Competing interests}

The authors declare that they have no competing interests.

\section{Author details}

${ }^{1}$ Aviation Career Center, CEO, 2312 Orehova vas, Slovenia. ${ }^{2}$ Department for Simulations and Distance Learning, University of Defense in Belgrade, Pavla Jurišića Šturma 1, 11000 Belgrade, Republic of Serbia. ${ }^{3}$ Faculty of Technical Sciences, University of Novi Sad, Trg Dositeja Obradovića 6, Novi Sad, Republic of Serbia. ${ }^{4}$ Ministry of Energy and Mining of Russian Federation, Moscow, Russian Federation. ${ }^{5}$ Faculty of Organizational Sciences, University of Maribor, Kidričeva cesta 55a, Kranj, Slovenia. 
Received: 7 September 2021 Accepted: 7 January 2022

Published online: 13 January 2022

\section{References}

1. Razmjoo AA, Sumper A, Davarpanah A (2020) Energy sustainability analysis based on SDGs for developing countries. Energy Source Pat A 42:1041-1056. https://doi.org/10.1080/15567036.2019.1602215

2. Bianco V, Proskuryakova L, Starodubtseva A (2021) Energy inequality in the Eurasian Economic Union. Renew Sust Energ Rev 146:111155. https:// doi.org/10.1016/j.rser.2021.111155

3. Sinha A (2017) Inequality of renewable energy generation across OECD countries: a note. Renew Sust Energy Rev 79:9-14. https://doi.org/10. 1016/j.rser.2017.05.049

4. Hu H, Xie N, Fang D, Zhang X (2018) The role of renewable energy consumption and commercial services trade in carbon dioxide reduction: evidence from 25 developing countries. Appl Energy 218:1229-1244. https://doi.org/10.1016/j.apenergy.2017.12.019

5. Wu Y, Zhu Q, Zhu B (2018) Comparisons of decoupling trends of global economic growth and energy consumption between developed and developing countries. Energy Policy 116:30-38. https://doi.org/10.1016/j. enpol.2018.01.047

6. Fathi B, Ashena M, Bahari AL (2021) Energy, environmental, and economic efficiency in fossil fuel exporting countries: a modified data envelopment analysis approach. Sustain Prod Consum 26:588-596. https://doi.org/10. 1016/j.spc.2020.12.030

7. Li F, Cunyi Y, Zhenghui L, Failler P (2021) Does geopolitics have an impact on energy trade? Empir Res Emerg Ctries Sustain 13:5199. https://doi.org/ 10.3390/su13095199

8. Gunnarsdottir I, Davidsdottir B, Worell E, Sigurgeirsdottir S (2020) Review of indicators for sustainable energy development. Renew Sust Energy Rev 133:110294. https://doi.org/10.1016/j.rser.2020.110294

9. Banerjee SG, Moreno FA, Sinton J, Primiani T, Seong J. Regulatory Indicators for Sustainable Energy: A Global Scorecard for Policy Makers. World Bank, Washington, DC. ( World Bank. https://openknowledge.worldbank. org/handle/10986/26099 2017. Accessed 15 June 2021.

10. Razmjoo AA, Sumper A, Davarpanah A (2019) Development of sustainable energy indexes by the utilization of new indicators: a comparative study. Energy Rep 5:375-383. https://doi.org/10.1016/j.egyr.2019.03.006

11. Thess A, Klein M, Nienhaus K, Pregger T (2020) Global carbon surcharge for the reduction of anthropogenic emission of carbon dioxide. Energy Sustain Soc 10:9. https://doi.org/10.1186/s13705-020-0242-z

12. Akam D, Owolabi O, Nathaniel SP (2021) Linking external debt and renewable energy to environmental sustainability in heavily indebted poor countries: new insights from advanced panel estimators. Environ Sci Pollut Res. https://doi.org/10.1007/s11356-021-15191-9

13. Lior N, Radovanović M, Filipović S (2018) Comparing sustainable development measurement based on different priorities: sustainable development goals, economics, and human well-being-Southeast Europe case. Sustain Sci 13:973-1000. https://doi.org/10.1007/s11625-018-0557-2

14. Jin T, Kim J (2019) A comparative study of energy and carbon efficiency for emerging countries using panel stochastic frontier analysis. Sci Rep 9:6647. https://doi.org/10.1038/s41598-019-43178-7

15. Ozkan B, Ozturk I (2019) Renewable energy consumption-economic growth nexus in emerging countries: a bootstrap panel causality test. Renew Sust Energ Rev 104:30-37. https://doi.org/10.1016/j.rser.2019.01. 020

16. Narula K, Reddy BS (2015) Three blind men and an elephant: The case of energy indices to measure energy security and energy sustainability. Energy J 80:148-158. https://doi.org/10.1016/j.energy.2014.11.055

17. Grigoroudis E, Kouikoglou VS, Phillis YA (2019) Energy sustainability: a definition and assessment model. Oper Res 21:1845-1885. https://doi. org/10.1007/s12351-019-00492-2

18. Ang BW, Choong WL, Ng TS (2015) Energy security: definitions, dimensions and indexes. Renew Sust Energ Rev 42:1077-1093. https://doi.org/ 10.1016/j.rser.2014.10.064

19. Podbregar I, Šimić G, Radovanović M, Filipović S, Šprajc P (2020) International Energy Security Risk Index-- analysis of the methodological settings. Energies 13:3234. https://doi.org/10.3390/en13123234
20. Ninno Muniz R, Frizzo Stefenon S, Gouvêa Buratto W, Nied A, Meyer LH, Finardi EC, Marino Kühl R, Silva de Sá JA, Pereira R, da Rocha B (2020) Tools for measuring energy sustainability: a comparative review. Energies 13:2366. https://doi.org/10.3390/en13092366

21. Lehmann A, Masò J, Nativi S, Giuliani G (2020) Towards integrated essential variables for sustainability. Int J Digit Earth 13:158-165. https://doi. org/10.1080/17538947.2019.1636490

22. Ji Q, Zhang D, Geng J (2018) Information linkage, dynamic spill overs in prices and volatility between the carbon and energy markets. J Clean Prod 198:972-978. https://doi.org/10.1016/j.jclepro.2018.07.126

23. Dai S, Finkelman RB (2018) Coal as a promising source of critical elements: progress and future prospects. Int J Coal Geol 186:155-164. https://doi. org/10.1016/j.coal.2017.06.005

24. Strielkowski W, Lisin E, Astachova E (2017) Economic sustainability of energy systems and prices in the EU. Entrep Sustain Issues 4(4):591-600. https://doi.org/10.9770/jesi.2017.4.4(14)

25. Shan A, Ahmad M, Tan Z, Adebayo TS, Li RYM, Kirikkaleli D (2020) The role of energy prices and non-linear fiscal decentralization in limiting carbon emissions: tracking environmental sustainability. Energy J 234:121243. https://doi.org/10.1016/j.energy.2021.121243

26. Ike GN, Usman O, Alola AA, Sarkodie SA (2020) Environmental quality effects of income, energy prices and trade: the role of renewable energy consumption in G-7 countries. Sci Total Environ 721:137813. https://doi. org/10.1016/j.scitotenv.2020.137813

27. Swain RB, Karimu A (2020) Renewable electricity and sustainable development goals in the EU. World Dev 125:104693. https://doi.org/10.1016/j. worlddev.2019.104693

28. Chai J, Wang Y, Wang S, Wang Y (2019) A decomposition-integration model with dynamic fuzzy reconstruction for crude oil price prediction and the implications for sustainable development. J Clean Prod 229:775-786. https://doi.org/10.1016/j.jclepro.2019.04.393

29. Verbič M, Filipović S, Radovanović M (2017) Electricity prices and energy intensity in Europe. Util Policy 47:58-68. https://doi.org/10.1016/j.jup. 2017.07.001

30. Pach-Gurgul A, Śmiech S, Ulbrych M (2021) The effect of energy prices on energy intensity improvement-the case of the chemical industry in the V4 countries. Post-Commun Econ 33(5):566-580. https://doi.org/10.1080/ 14631377.2020 .1793605

31. Levinson A (2021) Energy intensity: deindustrialization, composition, prices, and policies in U.S. states. Resour Energy Econ 65:1010243. https:// doi.org/10.1016/j.reseneeco.2021.101243

32. Aminu N (2019) Energy prices volatility and the United Kingdom: evidence from a dynamic stochastic general equilibrium model. Energy J 172:487-497. https://doi.org/10.1016/j.energy.2019.01.092

33. Bednar DJ, Reames TG (2020) Recognition of and response to energy poverty in the United States. Nat Energy 5:432-439. https://doi.org/10. 1038/s41560-020-0582-0

34. Amoah A, Kwablah E, Korle K, Offei D (2020) Renewable energy consumption in Africa: the role of economic well-being and economic freedom. Energy Sustain Soc 10:32. https://doi.org/10.1186/ s13705-020-00264-3

35. De Laurentis C, Pearson PJG (2021) Policy-relevant insights for regional renewable energy deployment. Energy Sustain Soc 11:19. https://doi.org/ 10.1186/s13705-021-00295-4

36. Dutta A, Jana RK, Das D (2020) Do green investments react to oil price shocks? Implications for sustainable development. J Clean Prod 266:121956. https://doi.org/10.1016/j.jclepro.2020.121956

37. Fu JF, Alharthi M, Bhatti Z, Sun L, Rasul F, Hanif I, Iqbal W (2021) The dynamic role of energy security, energy equity and environmental sustainability in the dilemma of emission reduction and economic growth J Enviro Manage 280:111828. https://doi.org/10.1016/j.jenvman.2020. 111828

38. Apostoleris H, Sgouridis S, Stefancich M, Chiesa M (2019) Utility solar prices will continue to drop all over the world even without subsidies. Nat Energy 4:833-834. https://doi.org/10.1038/s41560-019-0481-4

39. Index of U.S. energy security risk. U.S. Chamber of Commerce, Washington DC, USA, 2020. https://www.uschamber.com/assets/documents/ globalenergyinstitute-usindex_web.pdf. Accessed 11 June 2021.

40. U.S. Energy Information Administration (2021) https://www.eia.gov/. Accessed 12 June 2021 
41. Natural Resources Canada (2021) https://www.nrcan.gc.ca/home Accessed 13 June 2021.

42. Brazilian National Agency of Petroleum, Natural Gas and Biofuels (2021) https://www.petrolplaza.com/organisations/969 Accessed 13 June 2021.

43. Ministry of the Peopl"s Power for Petroleum (2021) https://www.bname ricas.com/en/company-profile/ministerio-del-poder-popular-de-petro leo-minpet Accessed 13 June 2021.

44. Federal State Statistics Service (2021) https://eng.rosstat.gov.ru/ Accessed 14 June 2021

45. Türkiye Petrolleri (2021) https://www.tppd.com.tr/ Accessed 14 June 2021.

46. Indian Oil (2021) https://iocl.com/ Accessed 15 June 2021.

47. National Bureau of Statistics of China (2021) http://www.stats.gov.cn/ english/ Accessed 15 June 2021.

48. Agency for Natural Resources and Energy of Japan (2021) https://www. enecho.meti.go.jp/en/ Accessed 16 June 2021.

49. South Korea: Statistical Database-Energy Sector (2021) https://kosis.kr/ eng/ Accessed 16 June 2021.

50. Eurostat database (2021) https://ec.europa.eu/eurostat/data/database Accessed 16 June 2021

51. Gas Alberta Inc. (2021) https://www.gasalberta.com/ Accessed 16 June 2021.

52. Petroleos de Venezuela SA (2021) http://www.pdvsa.com/index.php? lang=es Accessed 16 June 2021.

53. Coal India Ltd. (2021) https://www.coalindia.in/ Accessed 17 June 2021.

54. The Chinese General Chamber of Commerce (2021) https://www.cgcc. org.hk/zh/ Accessed 17 June 2021.

55. Apostoleris H, Ghaferi AA, Chiesa M (2020) What is going on with Middle Eastern solar prices, and what does it mean for the rest of us? Prog Photovol 29:638-648. https://doi.org/10.1002/pip.3414

56. IRENA_International Renewable Energy Agency (2021) https://www. irena.org/statistics. Accessed 17 June 2021.

57. Shaari MS, Abdul Karim Z, Zainol Abidin N (2020) The effects of energy consumption and national output on $\mathrm{CO}_{2}$ emissions: new evidence from OIC countries using a panel ARDL analysis. Sustainability 12:3312. https:// doi.org/10.3390/su12083312

58. Tronchin L, Manfren M, Nastasi B (2019) Energy analytics for supporting built environment decarbonisation. Energy Procedia 157:1486-1493. https://doi.org/10.1016/j.egypro.2018.11.313

\section{Publisher's Note}

Springer Nature remains neutral with regard to jurisdictional claims in published maps and institutional affiliations.

Ready to submit your research? Choose BMC and benefit from:

- fast, convenient online submission

- thorough peer review by experienced researchers in your field

- rapid publication on acceptance

- support for research data, including large and complex data types

- gold Open Access which fosters wider collaboration and increased citations

- maximum visibility for your research: over $100 \mathrm{M}$ website views per year

At BMC, research is always in progress.

Learn more biomedcentral.com/submissions 